\title{
Thallium Hyperaccumulation in Polish Populations of Biscutella laEvigata (BRASSicACEAE)
}

\author{
Matgorzata Wierzbicka ${ }^{1}$, Maria Pielichowska ${ }^{2}$, AgnieszKa Abratowska ${ }^{1}$, \\ BOGuSŁaW WiŁKOMIRSKI ${ }^{4}$, IRENA WySOCKA ${ }^{5}$, DOROTA PANUFNIK-MĘDRZYCKA ${ }^{1 *}$ \\ AND EwA BuLSKA ${ }^{3}$ \\ ${ }^{1}$ Department of Ecotoxicology, Institute of Botany, Faculty of Biology, \\ University of Warsaw, Miecznikowa 1, 02-096 Warsaw, Poland, \\ ${ }^{2}$ The Maria Grzegorzewska Academy of Special Education, Szczęśliwicka 40, \\ 02-353 Warsaw, Poland, \\ ${ }^{3}$ Faculty of Chemistry, Biological and Chemical Research Centre, \\ University of Warsaw, Żwirki $i$ Wigury 101, 02-089 Warsaw, Poland, \\ ${ }^{4}$ Department of Environmental Protection and Modeling, Faculty of Mathematics \\ and Natural Science, The Jan Kochanowski University in Kielce, \\ Świętokrzyska 15, 25-406 Kielce, Poland, \\ ${ }^{5}$ Central Chemical Laboratory, The Polish Geological Institute, \\ Rakowiecka 4, 00-975 Warsaw, Poland
}

Received February 25, 2016; revision accepted July 4, 2016

\begin{abstract}
Biscutella laevigata L. is known as a Tl hyperaccumulator. In Poland Biscutella laevigata occurs in the Tatra Mts (Western Carpathians) and on the calamine waste heap in Bolesław near Olkusz (Silesian Upland). The purpose of this work was to evaluate whether plants of both populations were able to accumulate an elevated amount of thallium in their tissues. The plants were cultivated in calamine soil in a glasshouse for a season and studied at different ages - from 2-week-old seedlings to 10-month-old adults. Additionally, the plants were grown for ten weeks in calamine soil with EDTA to enhance Tl bioavailability. The total content of Tl in plant tissues after digestion was determined by ICP-MS, whereas its distribution in leaves was studied by LA-ICP-MS. Of the total content of $\mathrm{Tl}$ in the soil in the range of (15.2-66.7) $\mathrm{mg} \cdot \mathrm{kg}^{-1} \mathrm{~d} . \mathrm{m}$., only (1.1-2.1) $\mathrm{mg} \cdot \mathrm{kg}^{-1} \mathrm{~d} . \mathrm{m}$. was present in a bioavailable form. The mean content in all the plants grown on the soil without EDTA was $98.5 \mathrm{mg} \cdot \mathrm{kg}^{-1} \mathrm{~d} . \mathrm{m}$. The largest content was found in leaves - $164.9 \mathrm{mg} \cdot \mathrm{kg}^{-1} \mathrm{~d} . \mathrm{m}$. (max. $588.2 \mathrm{mg} \cdot \mathrm{kg}^{-1} \mathrm{~d} . \mathrm{m}$.). In the case of plants grown on the soil enriched with EDTA, the mean content in plants increased to $108.9 \mathrm{mg} \cdot \mathrm{kg}^{-1} \mathrm{~d} . \mathrm{m}$., max. in leaves $-138.4 \mathrm{mg} \cdot \mathrm{kg}^{-1} \mathrm{~d} . \mathrm{m}$. (max. $1100 \mathrm{mg} \cdot \mathrm{kg}^{-1} \mathrm{~d} . \mathrm{m}$.). The translocation factor was 6.1 in the soil and 2.2 in the soil with EDTA; the bioconcentration factor amounted to 10.9 and 5.8, respectively. The plants from both populations did not contain a Tl amount clearly indicating hyperaccumulation (100-500 $\left.\mathrm{mg} \cdot \mathrm{kg}^{-1} \mathrm{~d} . \mathrm{m}.\right)$, however, high $(>1)$ translocation and bioconcentration factors suggest such an ability. It is a characteristic species-wide trait; B. laevigata L. is a facultative $\mathrm{Tl}$ hyperaccumulator. The largest $\mathrm{Tl}$ amount was located at the leaf base, the smallest at its top. Thallium also occurred in trichomes, which was presented for the first time; in this way plants detoxify Tl in the above-ground parts. Leaves were much more hairy in the Bolesław plants. This is an adaptation for growth in the extreme conditions of the zinc-lead waste heap with elevated Tl quantity.
\end{abstract}

Keywords: Biscutella laevigata L., hyperaccumulator, LA-ICP-MS, metal translocation, thallium, trichomes

\footnotetext{
*Corresponding author, email: dmedrzycka@uw.edu.pl
} 


\section{INTRODUCTION}

Thallium is known as a highly toxic metal. The biggest anthropogenic sources of thallium are carbon incineration, heavy metal ores containing thallium, non-ferrous metal smelting and refineries (Sager, 1994). Thallium is extremely toxic to people, animals and plants. It is similar to potassium and therefore disturbs the basic metabolism of cells (Scheckel et al., 2007).

Contamination of the environment with thallium in Poland has not been investigated for quite a long time. Over the last 15 years, only a few examinations have been performed (Dmowski et al., 1998; Dmowski, 2000; Dmowski and Badurek, 2001, 2002; Lis et al., 2003). In feathers of magpies (Pica pica), caught in the environs of Bolesław near Olkusz and the smelter in Bukowno (Bolesław Mining and Metallurgical Plant, ZGH Bolesław), the thallium content was a few hundred times higher than in feathers of magpies inhabiting areas in Poland that were non-industrialized and uncontaminated (Dmowski, 2000). The contamination of the Bukowno surroundings was caused by emission of chimney dust from the ZGH Bolesław plant and dust blown by wind from the surface of the tailing pond. A sample from the heap edge contained $149 \mathrm{mg} \cdot \mathrm{kg}^{-1} \mathrm{~d} . \mathrm{m}$. of $\mathrm{Tl}$, whereas from the flotation tailings - 30-40 mg. $\mathrm{kg}^{-1} \mathrm{~d} . \mathrm{m}$. (Dmowski and Badurek, 2002). For comparison, $\mathrm{Tl}$ content in uncontaminated soil amounts to $0.2-1 \mathrm{mg} \cdot \mathrm{kg}^{-1} \mathrm{~d} . \mathrm{m}$. (Crößmann, 1984) or $0.02-2.8 \mathrm{mg} \cdot \mathrm{kg}^{-1} \mathrm{~d} . \mathrm{m}$. (Kabata-Pendias, 2011).

Plant species able to hyperaccumulate heavy metals in the above-ground parts are constantly sought because of their potential usefulness for soil remediation (phytoremediation) and isolation of precious metals from the soil (phytomining). Thallium is a very costly metal, similarly to gold (Scheckel et al., 2007; Sheoran et al., 2009) and this is why plant species hyperaccumulating it are worth a detailed study.

According to the literature, a plant species could be considered a hyperaccumulator when a content of at least $500 \mathrm{mg} \cdot \mathrm{kg}^{-1} \mathrm{~d} . \mathrm{m}$. is detected in the above-ground parts of plants (Anderson et al., 1999; Leblanc et al., 1999). A lower content of thallium hyperaccumulation in leaves, i.e., $100 \mu \mathrm{g} \cdot \mathrm{g}^{-1} \mathrm{~d} . \mathrm{m}$. (100 $\mathrm{mg} \cdot \mathrm{kg}^{-1} \mathrm{~d} . \mathrm{m}$.) has been recently proposed (van der Ent et al., 2013).

Up to now, only a few plant species have been recognized as thallium hyperaccumulators, namely Iberis intermedia, Biscutella laevigata (Anderson et al., 1999; Leblanc et al., 1999; LaCoste et al., 1999, 2001; Scheckel et al., 2007; Sheoran et al., 2009; Pošćić et al., 2013, 2015) and Silene latifolia (Escarrè et al., 2011). In the study of the Biscutella laevigata plants growing in St. Laurent le Minier, southern France, the Tl content in the soil was $25 \mathrm{mg} \cdot \mathrm{kg}^{-1} \mathrm{~d} . \mathrm{m}$. (from 11 to $57 \mathrm{mg} \cdot \mathrm{kg}^{-1} \mathrm{~d} . \mathrm{m}$.), and in the plants $504 \mathrm{mg} \cdot \mathrm{kg}^{-1} \mathrm{~d} . \mathrm{m}$. (from 65 to $3920 \mathrm{mg} \cdot \mathrm{kg}^{-1} \mathrm{~d} . \mathrm{m}$.) (LaCoste et al., 1999).

In Poland B. laevigata occurs also in the metalliferous soil in the environs of Bolesław near Olkusz (Godzik, 2015). This is the utmost northern isolated location of this species. Also noted is B. laevigata subsp. gracilis Mach.-Laur. in the Tatra Mountains (southern Poland), where lies the northern limit of the continuous species range. The locations in Bolesław and the Tatra Mts. are $120 \mathrm{~km}$ away from each other (Szafer, 1927; Dobrzańska, 1955; Godzik, 1984, 1991; Grodzińska et al., 2000; Grodzińska and Szarek-Łukaszewska, 2002; Szarek-Łukaszewska and Niklińska, 2002; Wierzbicka and Pielichowska, 2004). B. laevigata is a montane species and, according to Szafer (1927), it can be found higher than $2128 \mathrm{~m}$ a.s.l., where it grows on calcareous rocks and screes; it occupies dry, warm and sunny habitats on the foreland of mountains and on lowlands. In the area of the calamine waste heap in Bolesław near Olkusz, B. laevigata grows in hollows and on so-called warpie (piles of calamine ores), the remains of mining outcrops, as well as freshly made piles (Wójcicki, 1913; Dobrzańska, 1955; Grodzińska et al., 2000).

The waste heap near Olkusz is located in the Silesian Upland, within the Garb Tarnogórski mesoregion. A part of this area forms a hummock built of Triassic limestones and ore-bearing dolomites. These formations contain zinc and lead ore bodies which are accompanied by iron ores. Lead ores also contain small amounts of silver, cadmium and thallium (Dobrzańska, 1955; Grodzińska et al., 2000). The opencast mining in this region began in the $13^{\text {th }}$ century. In the surroundings of Bolesław intense mining works continued till the 1930s (Grodzińska et al., 2000; Grodzińska and SzarekŁukaszewska 2002).

In order to examine the elemental composition of biological objects Inductively Coupled Plasma Mass Spectrometry (ICP-MS) becomes the method of choice due to its selectivity and sensitivity. It can be used for determination of the total content of elements of interest in the aliquots obtained after digestion or extraction. When coupled with laser ablation (LA), it can be used for examination of the element distribution directly in solids (Wysocka, 2004; Hanć et al., 2009; Wierzbicka et al., 2007).

The aim of this study was to evaluate whether plants of the two B. laevigata populations occurring in Poland accumulate such an amount of thallium in their tissues that they could be considered capable of hyperaccumulating this element. 


\section{MATERIALS AND METHODS}

\section{STUDIED PLANTS}

Two isolated population of Biscutella laevigata were studied. The plants were grown in laboratory conditions from seeds collected in two locations in Poland:

- a zinc-lead (calamine) waste heap in Bolesław near Olkusz - the population is named in this work the "calamine population",

- the Western Tatra Mountains - the population from this location is named in this work the "montane population".

\section{PLANT CULTIVATION IN CALAMINE SOIL}

The $B$. laevigata plants of the calamine and montane populations were cultivated in calamine soil in laboratory conditions. The accumulation of thallium by plants of different ages, from 2 -week-old seedlings to 10-month-old adults, was evaluated.

Seeds from both populations were incubated on wet blotting paper in Petri dishes for two weeks. Next, germination and cultivation of the plants was carried out in garden soil, at different times to obtain plants varied in age: 2-week-, 1-, 2- and 10-month-old ones. The plants of four groups were replanted partly in the calamine soil brought from the zinc-lead waste heap in Bolesław near Olkusz and partly in garden soil (control). The cultivation was continued for five months. It was done in a glasshouse, under the long-day conditions $\left(16 \mathrm{~h} / 8 \mathrm{~h}\right.$ ) and at the temperature of $29^{\circ} \mathrm{C} / 18^{\circ} \mathrm{C}$ (day/ night). The plants were watered with distilled water twice a week. Altogether 112 plants were cultivated.

\section{PLANT CULTIVATION IN CALAMINE SOIL WITH ADDED EDTA}

To enhance the bioavailability of metals, an EDTA solution $\left(\mathrm{Na}_{2} \mathrm{H}_{2}\right.$ EDTA $\left.2 \mathrm{H}_{2} \mathrm{O}\right)$ was added to calamine soil. The salt solubility is equal to $11.1 \mathrm{~g} / 100 \mathrm{ml} \mathrm{H}_{2} \mathrm{O}$ at temp. $21^{\circ} \mathrm{C}$. With many di-, tri- and tetravalent cations EDTA forms persistent, easily water-soluble chelats, which is why this compound is quite often used for enhancing bioavailability of metals in soil (Szmal and Lipiec, 1996; Epstein et al., 1999; Heil et al., 1999; Liphadzi et al., 2003; Minczewski and Marczenko, 2004; Turgut et al., 2004).

The plants of the calamine and montane populations were grown in the following variants: calamine soil with $1.5 \mathrm{mmol} \cdot \mathrm{kg}^{-1}$ EDTA; garden soil with $1.5 \mathrm{mmol} \cdot \mathrm{kg}^{-1}$ EDTA; calamine soil without EDTA; and garden soil without EDTA.

Seeds of the plants from both populations were sown on wet blotting paper in Petri dishes. The seedlings were transferred to garden soil and next, they were cultivated for two months. Thereafter, the plants were moved from the garden soil, well washed and transplanted to pots with calamine soil as well as calamine soil with EDTA. The plants cultivated in the garden soil and the garden soil with EDTA were controls.

The calamine soil was prepared in the following way: the calamine substratum was sieved through a sieve with a mesh size of $2 \mathrm{~mm}$ and divided into two parts. One part was left without EDTA and the other was mixed with $1.5 \mathrm{mmol} \cdot \mathrm{kg}^{-1}$ EDTA many times and left for four and a half weeks. The garden soil was prepared in the same way. Additionally, the calamine soil was triturated by hand, and the garden soil was mixed with $2-\mathrm{mm}$ glass pellets, in the ratio 3:1.

During cultivation the plants were watered with distilled water twice a week. The cultivation was continued for two and a half months and was done in a glasshouse, under the long-day conditions ( $16 \mathrm{~h} / 8 \mathrm{~h}$ ) and at the temperature of $29^{\circ} \mathrm{C} / 18^{\circ} \mathrm{C}$ (day/ night). Altogether, 46 plants were grown.

\section{ELEMENTAL COMPOSITION OF PLANTS AND SOIL AS WELL AS THALLIUM DISTRIBUTION IN LEAVES - INSTRUMENTATION}

Inductively Coupled Plasma Mass Spectroscopy (ICP-MS): an inductively coupled plasma mass spectrometer ELAN 6100 DRC (Perkin Elmer SCIEX, Canada; www.perkinelmer.com) was used for measurement of the total content of thallium in the soil and the plants after digestion as well as after extraction.

Laser Ablation Inductively Coupled Plasma Mass Spectroscopy (LA-ICP-MS): an inductively coupled plasma mass spectrometer ELAN DRC II (Perkin Elmer SCIEX, Canada; www.perkinelmer. com) equipped with the laser ablation system LSX500 (CETAC, USA; www.cetac.com) was used. The LSX-500 combines a stable, environmentally sealed 266 nm UV laser (Nd-YAG, solid state, Q-switched) with a high sampling efficiency, variable 1 to $20 \mathrm{~Hz}$ pulse repetition rate and maximum energy up to $6 \mathrm{~mJ} /$ pulse. In order to evaluate the thallium distribution in leaves, $205 \mathrm{Tl} / 13 \mathrm{C}$ was measured, and 13C was used as an internal standard.

All operating conditions of LA-ICP-MS and ICPMS used in these studies are summarized in Tab. 1.

An ETHOS-PLUS (Milestone) microwave system was used for plant tissues and soil digestion. The mineralization time/power program was as follows: $5 \mathrm{~min}$. at $100 \mathrm{~W} ; 10 \mathrm{~min}$. at $800 \mathrm{~W} ; 15 \mathrm{~min}$. of cooling.

In order to assure the accuracy of results, two standard reference materials were used: Pine 
TABLE 1. Operating parameters of ICP-MS and LA-ICP-MS instrumentations.

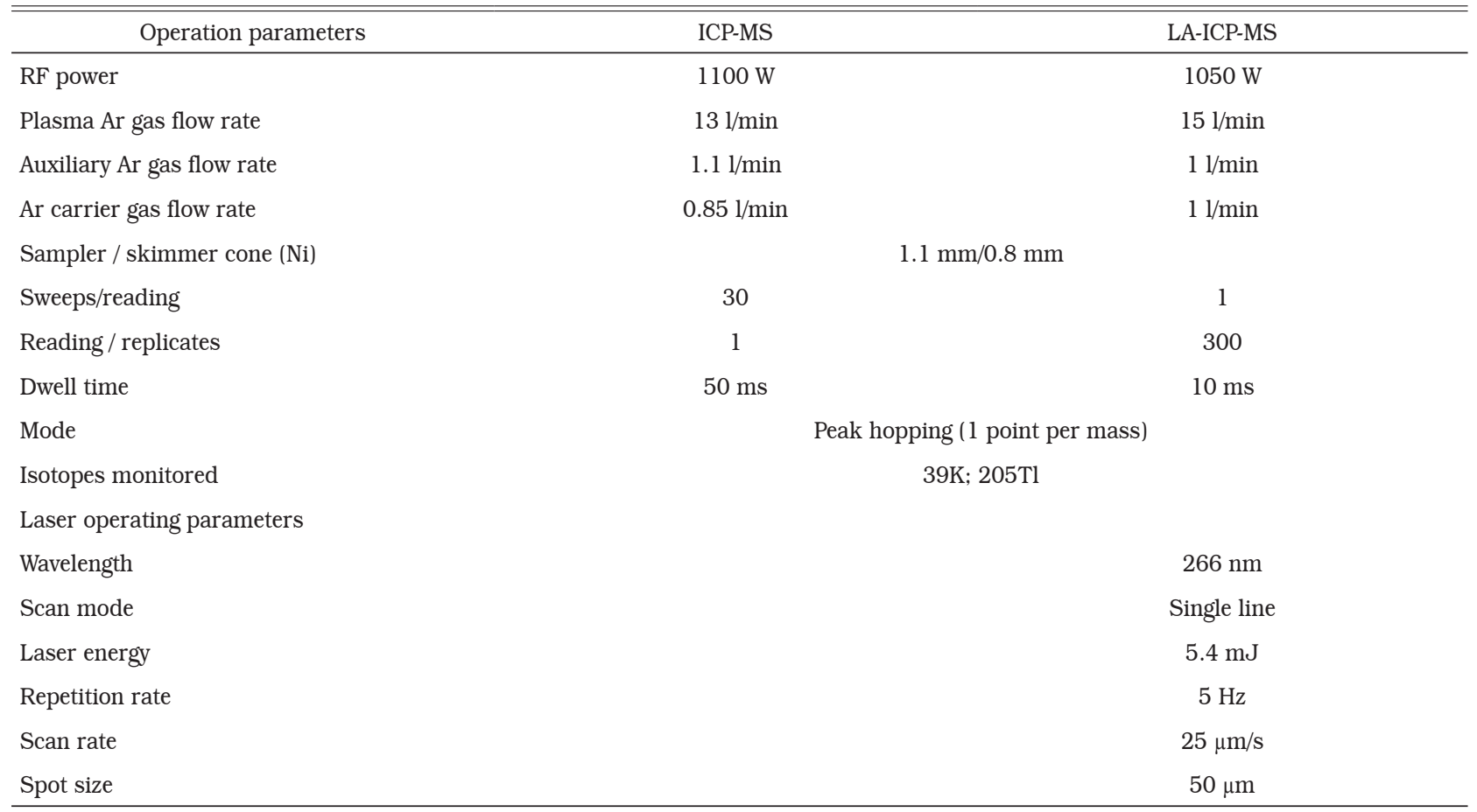

Needles 1575 and Spinach 1570a from NIST as well as Soil NCS DC 73322 (GBW07404) from the China National Analysis Center for Iron \& Steel.

\section{THALLIUM AND POTASSIUM CONTENT} IN PLANTS AND SOIL

After the cultivation had been ended, the plants were well washed and divided into roots and fresh and dry leaves, which were washed with distilled water ( 3 times), then dried on blotting paper. Next, the plant tissues that had been weighed and dried at $100^{\circ} \mathrm{C}$ to a constant mass were ground in an agate mortar. The plant tissues were digested with the use of $6 \mathrm{ml}$ of the $69 \%$ mixture of $\mathrm{HNO}_{3}: \mathrm{H}_{2} \mathrm{O}_{2}$ (5:1). After digestion had been completed, thallium and potassium contents were determined by ICPMS (Tab. 1). The soil from the calamine waste heap in Bolesław near Olkusz was dug from the growth place of plants (the soil associated with rhizosphere). The soil was sieved through a sieve with a mesh size of $1 \mathrm{~mm}$, dried at $80^{\circ} \mathrm{C}$, and ground in an agate ball mill. The mixture of $6 \mathrm{ml}$ of $\mathrm{HCl}$ and $2 \mathrm{ml}$ of $\mathrm{HNO}_{3}$ was poured onto the $1 \mathrm{~g}$ sample weights. They were heated in an open system, cooled and infiltrated. Next, $50 \mathrm{ml}$ of distilled water was added to the filtrate. The determination of thallium and potassium was performed by means of ICP-MS (Tab. 1).
In order to control the $\mathrm{pH}$ of the soil, around $50 \mathrm{ml}$ of deionized water was added to a 5-g soil sample and stored for 24 hours. The $\mathrm{pH}$ of the solution above the soil sediment at $25^{\circ} \mathrm{C}$ was measured (Wachalewski, 1999).

\section{EXTRACTION AND DETERMINATION OF THALLIUM CONTENT IN SOIL}

In order to determine the amount of thallium bound to various soil components (and thus differing in its bioavailability), single extraction with various media was applied. The assays were made for the vegetated calamine soil. The following extractants were used: 1) $0.01 \mathrm{~mol} / 1 \mathrm{CaCl}_{2}$; 2) $0.02 \mathrm{~mol} / \mathrm{l}$ EDTA in acetic buffer, $\mathrm{pH}$ 4.65. A 5-g sample was extracted with $50 \mathrm{ml}$ of the extractant at room temperature for 16 hours. The Tl content was determined by ICP-MS.

\section{EVALUATION OF THALLIUM DISTRIBUTION IN LEAVES}

Dried leaves of $B$. laevigata plants from the calamine and montane populations were used in this study. The plants were cultivated in: calamine soil with $3 \mathrm{mmol} \cdot \mathrm{kg}^{-1}$ EDTA; and garden soil without EDTA.

In order to examine thallium distribution in leaves, an individual leaf was exposed to a laser 
beam along four lines (two lines in a petiole, one in the middle of a lamina, and one at the top of a lamina). In addition, trichomes along the lamina edge protruding outside it were studied.

Following the signals from $205 \mathrm{Tl}$ and 13C, obtained as a result of the laser beam scan along the lines, profiles of thallium distribution in both the lamina and trichomes were obtained.

\section{VISUALISATION OF HEAVY METALS IN TRICHOMES}

The heavy metal presence in trichomes of plants from both populations was detected by the nonspecific histochemical method with the use of dithizone (diphenylthiocarbazone) (Seregin and Ivanov, 1997; Wierzbicka and Pielichowska, 2004; Olko et al., 2008). This compound forms chelats with metal cations, visible under the light microscope as variously shaped black deposits.

\section{STATISTICAL ANALYSIS}

The data were analysed statistically in PAST 2.17c software. All effects were tested by the non-parametric Kruskall-Wallis test with post-hoc pairwise comparisons using the Mann-Whitney U test.

\section{RESULTS}

\section{THALLIUM AND POTASSIUM IN CALAMINE SOIL}

The total content of thallium in the calamine soil was checked in two types of habitats. In the bare calamine soil, where plants (including B. laevigata) just begin to grow and in the already vegetated soil with humus, in the rhizosphere.

The thallium content amounted to $66.7 \mathrm{mg} \cdot \mathrm{kg}^{-1} \mathrm{~d} . \mathrm{m}$. and $15.2 \mathrm{mg} \cdot \mathrm{kg}^{-1} \mathrm{~d} . \mathrm{m}$., respectively (Tab. 2). The avail- ability of thallium for plants estimated by the extraction in EDTA was relatively low $\left(16.4 \mathrm{mg} \cdot \mathrm{kg}^{-1} \mathrm{~d} . \mathrm{m}\right.$. and $3.1 \mathrm{mg} \cdot \mathrm{kg}^{-1} \mathrm{~d} . \mathrm{m}$., respectively), similarly in $\mathrm{CaCl}_{2}$ (2.1 mg. kg ${ }^{-1}$ d.m. and $1.1 \mathrm{mg} \cdot \mathrm{kg}^{-1}$ d.m., respectively). The calamine soil was reasonably rich in potassium (3004 mg. $\mathrm{kg}^{-1} \mathrm{~d} . \mathrm{m}$.) in comparison with, e.g., the garden soil or the geochemical background in the area of Poland, and its $\mathrm{pH}$ was slightly alkaline (7.4-7.8) (Tab. 2).

\section{THALLIUM CONTENT IN B. LAEVIGATA PLANTS OF CALAMINE AND MONTANE POPULATIONS}

Plants of different ages (from 2-week-old seedlings to 40-week-old adults) were cultivated for five months in calamine soil. It was found that thallium was taken up by plants of both populations (Tab. 3). The mean Tl content in plants amounted to $98.5 \mathrm{mg} \cdot \mathrm{kg}^{-1} \mathrm{~d} . \mathrm{m}$. (max. $1100 \mathrm{mg} \cdot \mathrm{kg}^{-1} \mathrm{~d} . \mathrm{m}$.). The highest content of $\mathrm{Tl}$ was found in shoots, $164.9 \mathrm{mg} \cdot \mathrm{kg}^{-1} \mathrm{~d} . \mathrm{m}$. on average (from 59.8 to $588.2 \mathrm{mg} \cdot \mathrm{kg}^{-1} \mathrm{~d} . \mathrm{m}$.). In roots the $\mathrm{Tl}$ content was much lower, $32 \mathrm{mg} \cdot \mathrm{kg}^{-1} \mathrm{~d} . \mathrm{m}$. on average (from 11.1 to $93.6 \mathrm{mg} \cdot \mathrm{kg}^{-1} \mathrm{~d} . \mathrm{m}$.). It turned out that the $\mathrm{Tl}$ content in plants depended on their age at the beginning of cultivation. Thallium was accumulated mostly by 2 -week-old seedlings (on average $219 \mathrm{mg} \cdot \mathrm{kg}^{-1} \mathrm{~d} . \mathrm{m}$. ), and much less effectively by older plants (on average $58.2 \mathrm{mg} \cdot \mathrm{kg}^{-1} \mathrm{~d} . \mathrm{m}$.). Noteworthy is the fact that among the older plants (4-, 8-, 40-week-old ones) the Tl content decreased from 74.5 to $43.4 \mathrm{mg} \cdot \mathrm{kg}^{-1} \mathrm{~d} . \mathrm{m}$.

It was found that $16 \%$ of the total thallium remained in roots, whereas $84 \%$ was transported to the above-ground parts (Fig. 3). The translocation factor (shoot : root ratio; Anderson et al., 1999) amounted on average to 6.1, whereas the bioconcentration factor (shoot : soil ratio; Anderson et al., 1999) was 10.9 .

TABLE 2. Thallium (Tl) and potassium (K) content [mg. $\left.\mathrm{kg}^{-1} \mathrm{~d} . \mathrm{m}.\right]$ and $\mathrm{pH}$ values ( $\mathrm{n}=3$ soil samples) in different soil types: pure calamine, vegetated calamine, garden soil in comparison with the geochemical background (Kabata-Pendias, 2011).

\begin{tabular}{|c|c|c|c|c|c|}
\hline \multirow[b]{2}{*}{ Soil } & \multicolumn{3}{|c|}{$\mathrm{Tl}$} & \multirow{2}{*}{  } & \multirow[b]{2}{*}{$\begin{array}{c}\mathrm{pH} \\
\text { N.S. }\end{array}$} \\
\hline & $\begin{array}{l}\text { Total content } \\
{\left[\underset{*}{\left[\mathrm{mg} \cdot \mathrm{kg}^{-1} \mathrm{~d} . \mathrm{m} .\right]}\right.}\end{array}$ & $\begin{array}{c}\text { Extracted by EDTA } \\
{\left[\underset{*}{\left[\mathrm{mg} \cdot \mathrm{kg}^{-1} \mathrm{~d} . \mathrm{m} .\right]}\right.}\end{array}$ & $\begin{array}{c}\text { Extracted by } \mathrm{CaCl}_{2} \\
{\left[\mathrm{mg}_{*} \mathrm{~kg}^{-1} \mathrm{~d} . \mathrm{m} .\right]}\end{array}$ & & \\
\hline Calamine & $66.7 \pm 0.4 \mathrm{a}$ & $16.4 \pm 1.6 \mathrm{a}$ & $2.1 \pm 0.6 \mathrm{a}$ & $3004 \pm 104 \mathrm{a}$ & $7.81 \pm 0.06 \mathrm{a}$ \\
\hline Vegetated calamine & $15.2 \pm 1.5 \mathrm{a}$ & $3.1 \pm 0.6 \mathrm{a}$ & $1.1 \pm 0.3 \mathrm{a}$ & not studied & $7.4 \pm 1.4 \mathrm{a}$ \\
\hline Garden & $0.0 \mathrm{a}$ & $0.0 \mathrm{a}$ & $0.0 \mathrm{a}$ & $417 \pm 61 \mathrm{a}$ & $4.97 \pm 0.08 \mathrm{a}$ \\
\hline $\begin{array}{l}\text { Geochemical } \\
\text { background }\end{array}$ & $0.02-2.8 \mathrm{a}$ & no data & no data & $130-20600$ a & $5-7$ a \\
\hline
\end{tabular}

Asterisks $\left({ }^{*}\right)$ denote significant effects found in Kruskall-Wallis test; N.S. - non-significant, ${ }^{*} \mathrm{p}<0.05,{ }^{* *} \mathrm{p}<0.01,{ }^{* * *} \mathrm{p}<0.001$. Lower-case letters denote statistically significant differences in Mann-Whitney post-hoc pairwise comparisons, $\mathrm{p}<0.05$. 
TABLE 3. Thallium content [ $\mathrm{mg} \cdot \mathrm{kg}^{-1} \mathrm{~d} . \mathrm{m}$.] in differently-aged B. laevigata plants of calamine (C) and montane (M) populations, grown in calamine soil for five months; $n=6$ mixed plant sample weights; mean of means for roots, fresh and dry leaves.

\begin{tabular}{|c|c|c|c|c|c|}
\hline \multirow{2}{*}{$\begin{array}{l}\text { Plant age } \\
\text { [weeks] }\end{array}$} & \multicolumn{2}{|c|}{$\mathrm{C}$} & \multicolumn{2}{|c|}{ M } & \multirow{2}{*}{$\begin{array}{c}\text { Overall effec } \\
{ }^{*} \\
\text { Mean }\end{array}$} \\
\hline & $\begin{array}{c}\text { Roots } \\
*\end{array}$ & $\begin{array}{c}\text { Shoots } \\
{ }_{*}\end{array}$ & $\begin{array}{c}\text { Roots } \\
\text { N.S. }\end{array}$ & $\underset{* * *}{\text { Shoots }}$ & \\
\hline 2 & $93.6 \pm 63 \mathrm{a}$ & $126.5 \pm 173 \mathrm{a}$ & $68.2 \pm 176 \mathrm{a}$ & $588.2 \pm 488 \mathrm{a}$ & $219.1 \mathrm{a}$ \\
\hline 4 & $19.0 \pm 7 \mathrm{a}$ & $155.4 \pm 54 \mathrm{~b}$ & $17.4 \pm 6 \mathrm{a}$ & $106.0 \pm 9 \mathrm{~b}$ & $74.5 \mathrm{ab}$ \\
\hline 8 & $17.0 \pm 4,5 \mathrm{a}$ & $122.5 \pm 21 \mathrm{~b}$ & $13.0 \pm 7 \mathrm{a}$ & $74.8 \pm 5 \mathrm{c}$ & $56.8 \mathrm{ab}$ \\
\hline 40 & $11.1 \pm 4 \mathrm{a}$ & $59.8 \pm 24 \mathrm{a}$ & $17.0 \pm 4.5 \mathrm{a}$ & $85.9 \pm 31$ bc & $43.4 \mathrm{~b}$ \\
\hline
\end{tabular}

Asterisks $\left({ }^{*}\right)$ denote significant effects found in Kruskall-Wallis test; N.S. - non-significant, ${ }^{*} \mathrm{p}<0.05,{ }^{* *} \mathrm{p}<0.01,{ }^{* * *} \mathrm{p}<0.001$. Lower-case letters denote statistically significant differences in Mann-Whitney post-hoc pairwise comparisons, $\mathrm{p}<0.05$.

\section{THALLIUM CONTENT IN B. LAEVIGATA PLANTS IN CALAMINE SOIL TREATED WITH EDTA}

During the cultivation of the B. laevigata plants, either in the pure calamine soil or the calamine soil with EDTA, the growth of the plants was not inhibited. On the contrary, the plants often gained bigger biomass than in the control (cultivated in the garden soil). The presence of EDTA in the calamine soil enhanced bioavailability of thallium; its content in plant organs increased by around $15 \mathrm{mg} \cdot \mathrm{kg}^{-1} \mathrm{~d} . \mathrm{m}$. on average (from $69.5 \mathrm{mg} \cdot \mathrm{kg}^{-1} \mathrm{~d} . \mathrm{m}$. to $84.8 \mathrm{mg} \cdot \mathrm{kg}^{-1} \mathrm{~d} . \mathrm{m}$.) (Tab. 4). The highest amount of $\mathrm{Tl}$ was found in fresh leaves (up to $306 \mathrm{mg} \cdot \mathrm{kg}^{-1} \mathrm{~d} . \mathrm{m}$.), nearly a $50 \%$ lower amount in roots, and the lowest content in dry leaves (21.1-37.1 mg. $\mathrm{kg}^{-1} \mathrm{~d} . \mathrm{m}$.). As a consequence of the presence of EDTA in the calamine soil, the content of $\mathrm{Tl}$ in the entire plants (roots and shoot) was on average equal to $109 \mathrm{mg} \cdot \mathrm{kg}^{-1} \mathrm{~d} . \mathrm{m}$.

In the control plants cultivated in the garden soil, the $\mathrm{Tl}$ content was very low and amounted to $0.05 \mathrm{mg} \cdot \mathrm{kg}^{-1} \mathrm{~d} . \mathrm{m}$. to max. $0.30 \mathrm{mg} \cdot \mathrm{kg}^{-1} \mathrm{~d} . \mathrm{m}$. The Tl content in plants of the calamine and montane populations did not differ, therefore the means for both populations were given together.

The $\mathrm{Tl}$ translocation factor for plants cultivated in the calamine soil with EDTA amounted on average to 2.2 , whereas the $\mathrm{Tl}$ bioconcentration factor had the mean value of 5.8 .

\section{POTASSIUM CONTENT IN B. LAEVIGATA PLANTS}

Thallium activity is primarily based on competition with potassium cations (Wenzel and Jockwer, 1999), therefore potassium content in the B. laevigata plants was also examined. The plants were cultivated in calamine soil without (control) and with the addition of EDTA as well as in garden soil (control) and garden soil with EDTA (control) (Tab. 5).

It was found that generally the potassium content in the plants cultivated in the calamine soil (with or without the addition of EDTA) was much lower (by more than 10 times) in comparison with the plants cultivated in the garden soil (with or without EDTA) - $3761 \mathrm{mg} \cdot \mathrm{kg}^{-1} \mathrm{~d} . \mathrm{m}$. and $42856 \mathrm{mg} \cdot \mathrm{kg}^{-1} \mathrm{~d} . \mathrm{m}$. on average, respectively. As the potassium content in both populations did not differ, the means for both populations were given together.

\section{THALLIUM DISTRIBUTION IN LEAVES (LA-ICP-MS)}

The distribution of thallium in the leaves of $B$. laevigata cultivated in the calamine soil with the addition of EDTA (plants cultivated in the garden soil without EDTA were controls) was examined by LA-ICP-MS.

As a result of the laser beam scan over the leaf lamina along indicated lines (Figs. 1 and 2), the profiles of the thallium distribution were obtained (Fig. 4). Next, peaks from consecutive profiles for

TABLE 4. Thallium content [mg. $\mathrm{kg}^{-1} \mathrm{~d} . \mathrm{m}$.] in B. laevigata plants grown for ten weeks in pure calamine soil and enriched with $1.5 \mathrm{mmol} \cdot \mathrm{kg}^{-1}$ EDTA; $\mathrm{n}=12$ mixed plant sample weights; mean of means for roots, fresh and dry leaves.

\begin{tabular}{lllll}
\hline \hline \multicolumn{1}{c}{ Soil } & Roots & Fresh leaves & Dry leaves & Mean \\
\hline Calamine & $51.5 \pm 23 \mathrm{a}$ & $135.7 \pm 45 \mathrm{a}$ & $21.2 \pm 2.5 \mathrm{a}$ & $69.5 \mathrm{a}$ \\
\hline Calamine with EDTA & $78.7 \pm 33.5 \mathrm{a}$ & $138.4 \pm 70.2 \mathrm{a}$ & $37.1 \pm 13.3 \mathrm{~b}$ & $84.8 \mathrm{a}$ \\
\hline
\end{tabular}

Lower-case letters denote statistically significant $(\mathrm{p}<0.05)$ differences in Mann-Whitney two sample U test. 


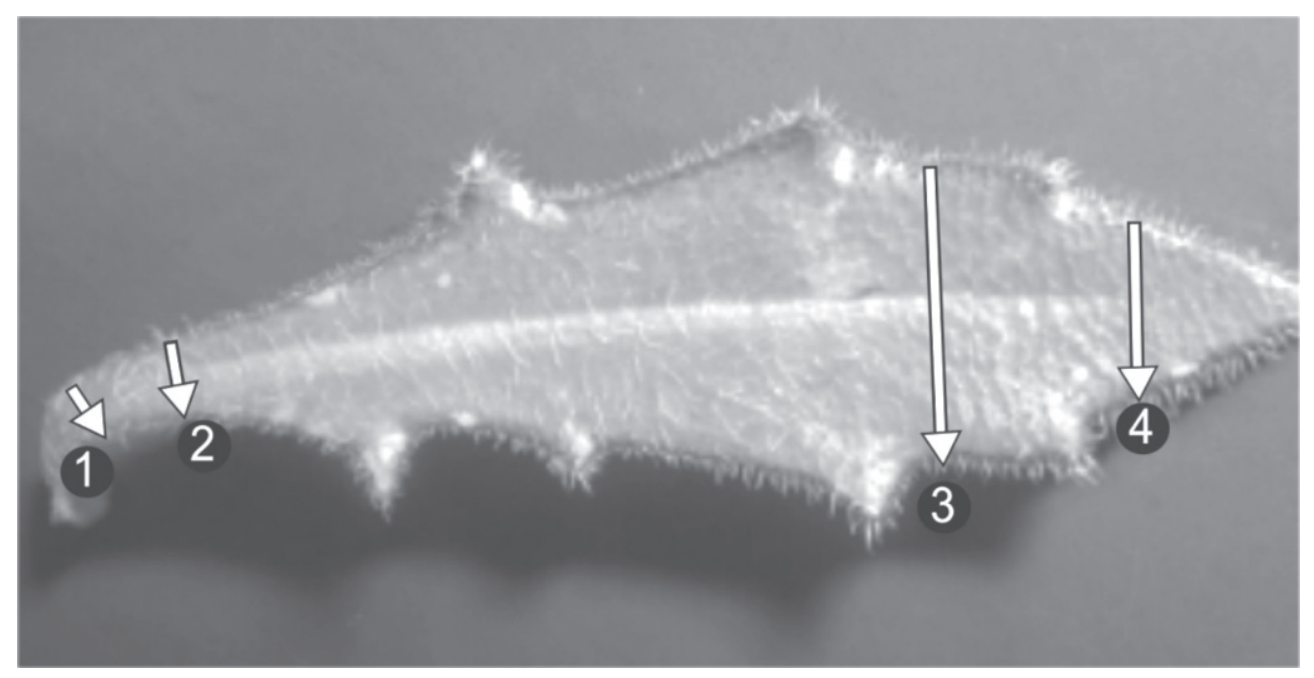

Fig. 1. Photo of a leaf examined by LA-ICP-MS. The arrows indicate the direction of the laser ablation line scan: mesophyll $\rightarrow$ vascular bundle $\rightarrow$ mesophyll consecutively in exposition lines from 1 to 4 .

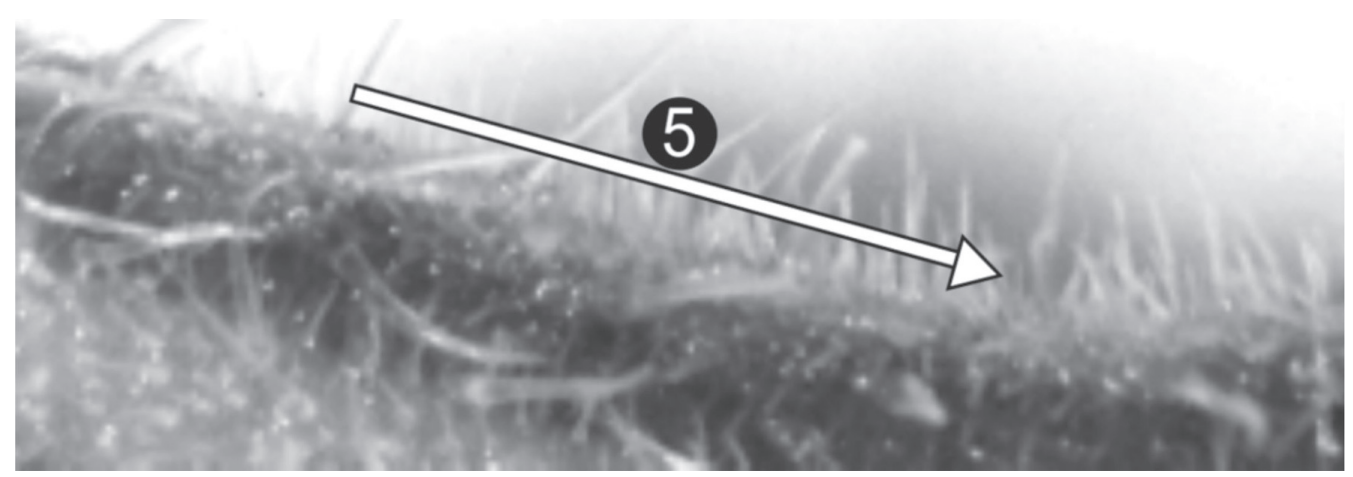

Fig. 2. Photo of trichomes on the leaf edge exposed to laser ablation via the line indicated by the arrow.

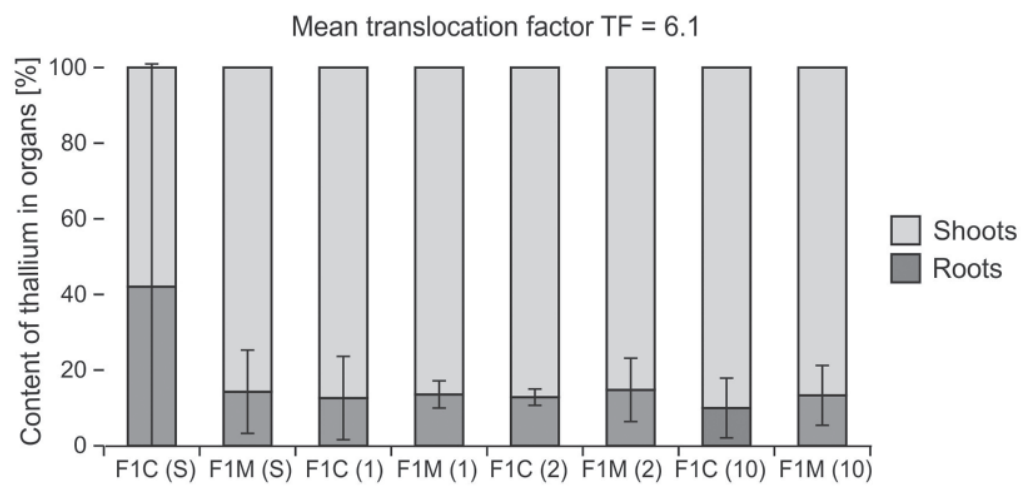

Fig. 3. Mean proportional thallium content [] in roots and shoots of B. laevigata plants from the calamine (C) and montane (M) population, cultivated from seeds (F1) in the calamine soil for five months. The age groups of plants at the beginning of cultivation: 2-week-old seedlings (S), 1-month-old (1), 2-month-old (2), 10-month-old (10) plants. Percentages were calculated as the thallium content in a shoot or a root [mg/kg d.m.], divided by the sum of the shoot and root $\mathrm{Tl}$ contents multiplied by $100 \%$. The translocation factor (TF): the ratio of the thallium content in shoots and roots; $\mathrm{n}=6$ mixed plant sample weights for each age group. 
TABLE 5. Potassium content [mg. $\left.\mathrm{kg}^{-1} \mathrm{~d} . \mathrm{m}.\right]$ in B. laevigata plants grown for ten weeks in: pure calamine soil, enriched with $1.5 \mathrm{mmol} \cdot \mathrm{kg}^{-1}$ EDTA, pure garden soil and enriched with $1.5 \mathrm{mmol} \cdot \mathrm{kg}^{-1}$ EDTA; $\mathrm{n}=12$ mixed plant sample weights; mean of means for roots, fresh and dry leaves.

\begin{tabular}{lcccc}
\hline \hline Soil & Roots*** & Fresh leaves*** & Dry leaves** & $\begin{array}{c}\text { Overall effect*** } \\
\text { Mean }\end{array}$ \\
\hline Calamine & $2005 \pm 306 \mathrm{a}$ & $8063 \pm 4866 \mathrm{a}$ & $4149 \pm 2657 \mathrm{a}$ & $4739 \mathrm{a}$ \\
\hline $\begin{array}{l}\text { Calamine } \\
\text { with EDTA }\end{array}$ & $1706 \pm 511 \mathrm{a}$ & $3608 \pm 434 \mathrm{a}$ & $3037 \pm 548 \mathrm{~b}$ & $2783 \mathrm{a}$ \\
\hline Garden & $10811 \pm 4008 \mathrm{~b}$ & $66164 \pm 28471 \mathrm{~b}$ & $43433 \pm 7841 \mathrm{c}$ & $40136 \mathrm{~b}$ \\
\hline $\begin{array}{l}\text { Garden } \\
\text { with EDTA }\end{array}$ & $7956 \pm 1670 \mathrm{~b}$ & $78854 \pm 18325 \mathrm{~b}$ & $49922 \pm 12600 \mathrm{c}$ & $45577 \mathrm{~b}$ \\
\hline
\end{tabular}

Asterisks $\left({ }^{*}\right)$ denote significant effects found in Kruskall-Wallis test; ${ }^{*} \mathrm{p}<0.05,{ }^{* *} \mathrm{p}<0.01,{ }^{* * *} \mathrm{p}<0.001$. Lower-case letters denote statistically significant differences in Mann-Whitney post-hoc pairwise comparisons, $\mathrm{p}<0.1$.

leaves of the experimental plants were added and averaged.

In all the plants growing in the calamine soil with EDTA, the largest amount of thallium occurred in the basal part of a leaf (Figs. 1 and 5, lines 1,2), and the smallest in its top part (Figs. 1 and 5, line 4). The thallium content in the leaves studied by ICP-MS amounted to $126 \mathrm{mg} \cdot \mathrm{kg}^{-1} \mathrm{~d} . \mathrm{m}$. This indicates high sensitivity of the method used, well suited for biological material.

\section{THALLIUM IN LEAF TRICHOMES (LA-ICP-MS)}

Trichomes on $B$. leavigata leaves are alive and single-celled. At the base of a leaf there is a large vacuole. Between the trichome cell and mesophyll cells of a leaf there exists a connection through plosmodesmata (data not presented).

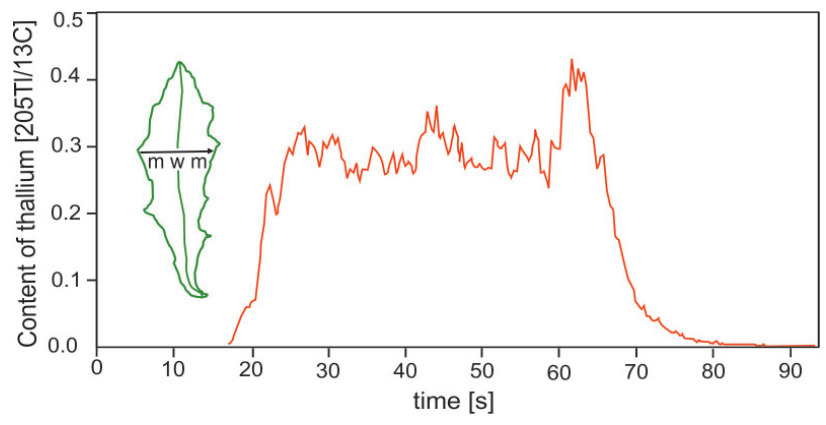

Fig. 4. LA-ICP-MS profile of thallium distribution in the leaf lamina of the montane plant $(\mathrm{M})$ cultivated in the calamine soil with $3 \mathrm{mmol} \cdot \mathrm{kg}^{-1}$ EDTA. The arrow: direction of the laser beam scan: mesophyll $(\mathrm{m}) \rightarrow$ vascular bundle $(\mathrm{w})$ $\rightarrow$ mesophyll (m). 205Tl/13C was measured, and 13C was used as an internal standard.
The investigation of the thallium presence in trichomes on the B. laevigata leaves was conducted by LA-ICP-MS. The laser beam was led along the leaf edge as shown in Fig. 2. In the leaf trichomes of both populations the presence of thallium was detected. The profiles obtained for different leaves enabled a relative assessment of the $\mathrm{Tl}$ amount accumulated there. In the leaves of plants cultivated in the calamine soil with EDTA, the amount of this element increased in comparison with the control (on the grounds of the profile reading): 300 times (calamine population) and 100 times (montane population). An exemplary profile for Tl in trichomes is shown in Fig. 6. After staining in dithizone there were observed deposits in the middle part of the trichome, in the central cell vacuole (Figs. 7 and 8 ).



(1)

(3)

(4)

Fig. 5. The mean thallium distribution along the leaf midrib in the calamine plants (C) cultivated in the calamine soil with the addition of $3 \mathrm{mmol} \cdot \mathrm{kg}^{-1}$ EDTA; $\mathrm{n}=3$ leaves. $205 \mathrm{Tl} / 13 \mathrm{C}$ was measured, and $13 \mathrm{C}$ was used as an internal standard. 


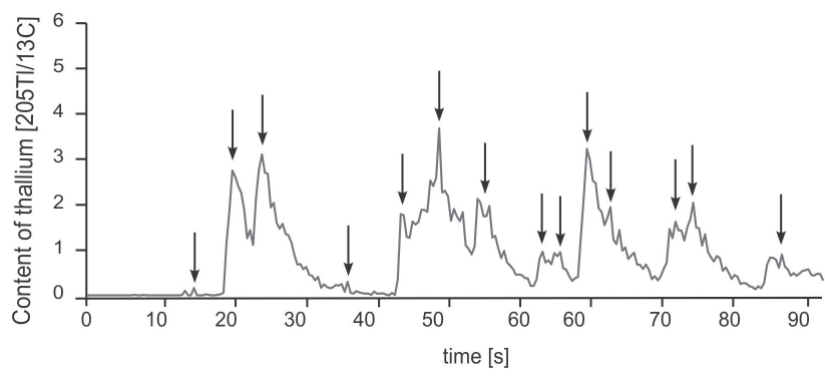

Fig. 6. Profile of $\mathrm{Tl}$ distribution, obtained by LA-ICP-MS method, in the leaf trichomes of the calamine plant (C) cultivated in the calamine soil with $3 \mathrm{mmol} \cdot \mathrm{kg}^{-1}$ EDTA. Every peak in the line marked with an arrow indicates a single trichome on the leaf. 205Tl/13C was measured, and 13C was used as an internal standard.

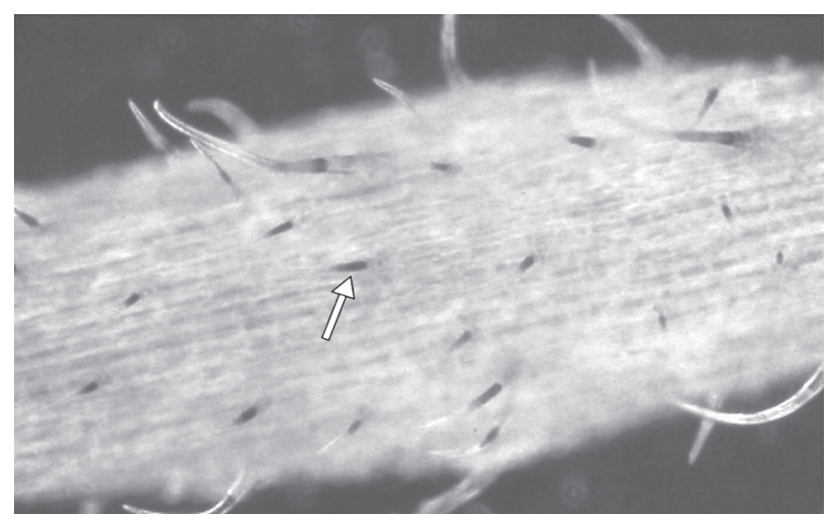

Fig. 7. Visualization of heavy metals in the trichomes (arrows) after the histochemical reaction. The plant cultivated in the calamine soil with $3 \mathrm{mmol} \cdot \mathrm{kg}^{-1}$ EDTA.

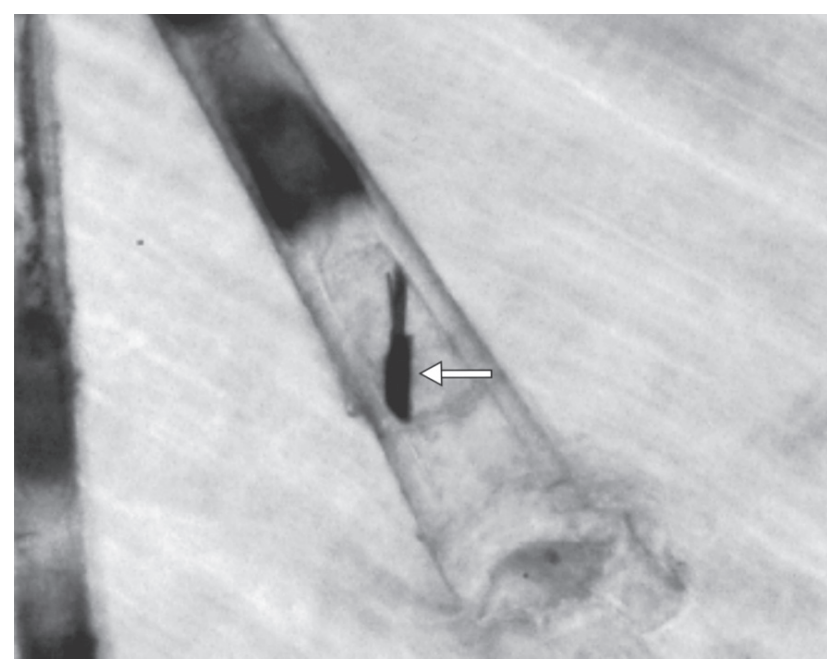

Fig. 8. Visualization of heavy metals in the trichome (arrow) after the histochemical reaction. The plant cultivated in the calamine soil with $3 \mathrm{mmol} \cdot \mathrm{kg}^{-1}$ EDTA.

\section{DISCUSSION}

\section{THALLIUM IN PLANTS}

In Poland in the metalliferous post-industrial areas of Olkusz, the amount of thallium in soils amounts to 29 to $44 \mathrm{mg} \cdot \mathrm{kg}^{-1} \mathrm{~d} . \mathrm{m}$., whereas in green plants, from 7.9 to $25.5 \mathrm{mg} \cdot \mathrm{kg}^{-1} \mathrm{~d} . \mathrm{m}$. (Kicińska, 2009). It is noteworthy that in green plants the $\mathrm{Tl}$ content should be $0.05 \mathrm{mg} \cdot \mathrm{kg}^{-1} \mathrm{~d} . \mathrm{m}$. (Kabata-Pendias, 2011). Our previous study (Wierzbicka et al., 2004) done in field conditions showed that metallophytes growing on the calamine waste heap in Bolesław near Olkusz contained thallium in shoots in the following contents: Plantago lanceolata - $54 \mathrm{mg} \cdot \mathrm{kg}^{-1} \mathrm{~d} . \mathrm{m}$., Silene vulgaris - $7 \mathrm{mg} \cdot \mathrm{kg}^{-1} \mathrm{~d} . \mathrm{m}$., Dianthus carthusianorum - $7 \mathrm{mg} \cdot \mathrm{kg}^{-1} \mathrm{~d} . \mathrm{m}$. That study did not show a significant amount of thallium in B. laevigata plants (Wierzbicka et al., 2004), although the species is included among $\mathrm{Tl}$ hyperaccumulators (Anderson et al., 1999; LaCoste et al., 1999; Leblanc et al., 1999; Pošcić et al., 2013, 2015).

In view of the foregoing, we decided to check in detail whether the B. laevigata plants occurring in Poland have the ability to hyperaccumulate thallium. Field studies always have some limitations. One of these is the fact that thallium in plants can be accumulated from two sources: it can be taken up by roots and transported to shoots, but it can also be found on the leaf surface due to dust fall containing Tl. Especially in plants equipped with very numerous trichomes on their leaves the contribution of this $\mathrm{Tl}$ pool might be crucial.

It seems that other authors did not pay particular attention to this problem in their studies (Anderson et al., 1999; LaCoste et al., 1999; Leblanc et al., 1999), and thus the results regarding $\mathrm{Tl}$ accumulation in B. laevigata plants may have come from both sources. It is worth stressing that only thallium absorbed by roots and transported to shoots can testify to its hyperaccumulation.

Extremely varied chemical composition of the soil is another limitation of field studies in postindustrial regions. In the area of a few square metres there may occur a highly toxic substratum next to a pure one. As was shown by Vanĕk et al. (2010), the $\mathrm{Tl}$ accumulation by plants depends on the soil type; a two- to threefold difference was found.

A diversified age of plants is the next limiting factor. B. laevigata is a perennial, and in the field there is no possibility of distinguishing older plants from younger ones. In studies on Sinapis alba it was shown that the $\mathrm{Tl}$ content in adult plants was three times lower than in the young ones (Vaněk et al., 2010).

Therefore, the detailed study of the ability of $B$. laevigata plants to accumulate thallium was 
done in controlled conditions, based on cultivation of plants in a glasshouse in the calamine soil containing Tl.

\section{BISCUTELLA LAEVIGATA - THALLIUM HYPERACCUMULATOR}

Thallium content in the soil of the calamine waste heap is varied. In this study it was shown that a threefold difference occurred in the $\mathrm{Tl}$ content between the bare soil without humus and places already possessing a thin litter layer and covered by plants $\left(66.7 \mathrm{mg} \cdot \mathrm{kg}^{-1} \mathrm{~d} . \mathrm{m}\right.$. and $15.2 \mathrm{mg} \cdot \mathrm{kg}^{-1} \mathrm{~d} . \mathrm{m}$., respectively).

Thallium distribution in plants depends on their age (Nriagu, 1988; Frattini, 2005). Usually, the highest content is recorded in seedlings, and with age of plants it gradually decreases. The Sinapis alba seedlings contained a few times more thallium than adult plants (Frattini, 2005).

In this respect the $B$. laevigata plants were studied in detail. Regardless of the population under study, the youngest (2-week-old) plants accumulated the largest thallium amount over five months. The $\mathrm{Tl}$ content was four times higher in seedlings than in the oldest plants $\left(219 \mathrm{mg} \cdot \mathrm{kg}^{-1} \mathrm{~d} . \mathrm{m}\right.$. and $43 \mathrm{mg} \cdot \mathrm{kg}^{-1} \mathrm{~d} . \mathrm{m}$. on average, respectively). Noteworthy is the fact that among the older plants, at the age of one to ten months, the amount of accumulated thallium (during the 5-month cultivation) decreased (from $74.5 \mathrm{mg} \cdot \mathrm{kg}^{-1} \mathrm{~d} . \mathrm{m}$. to $43.4 \mathrm{mg} \cdot \mathrm{kg}^{-1} \mathrm{~d} . \mathrm{m}$.). In this way it was proved that the $\mathrm{Tl}$ content in the B. laevigata plants depended on their age. However, over one growing season ( 5 months of cultivation) the $B$. laevigata plants contained altogether $98.5 \mathrm{mg} \cdot \mathrm{kg}^{-1} \mathrm{~d} . \mathrm{m}$. of $\mathrm{Tl}$ on average, from which the mean $\mathrm{Tl}$ content in the above-ground parts (in this species mainly leaves a rosette) amounted to $164.9 \mathrm{mg} \cdot \mathrm{kg}^{-1} \mathrm{~d}$.m. (from 59.8 to $588.2 \mathrm{mg} \cdot \mathrm{kg}^{-1} \mathrm{~d} . \mathrm{m}$.). This is a very high $\mathrm{Tl}$ content to be accumulated during only one growing season.

In further study $\mathrm{Tl}$ bioavailability was enhanced by the addition of EDTA to the calamine soil. In the $B$. laevigata plants cultivated in these conditions the $\mathrm{Tl}$ amount increased to such a level that whole plants contained on average $108.9 \mathrm{mg} \cdot \mathrm{kg}^{-1} \mathrm{~d} . \mathrm{m}$., of which $138.4 \mathrm{mg} \cdot \mathrm{kg}^{-1} \mathrm{~d} . \mathrm{m}$. (max. $\left.260 \mathrm{mg} \cdot \mathrm{kg}^{-1} \mathrm{~d} . \mathrm{m}.\right)$ was in fresh leaves.

These results should be compared with those of the field studies, on the grounds that $B$. laevigata was accepted as a Tl hyperaccumulator. The $\mathrm{Tl}$ content detected in leaves was then 504 (from 65 to 3920$) \mathrm{mg} \cdot \mathrm{kg}^{-1} \mathrm{~d} . \mathrm{m}$. and its content in the soil amounted to 25 (from 11 to 57 ) $\mathrm{mg} \cdot \mathrm{kg}^{-1} \mathrm{~d} . \mathrm{m}$. (LaCoste et al., 1999). The Tl amount in the $B$. laevigata plants discovered in this study does not reach the boundary value of $500 \mathrm{mg} \cdot \mathrm{kg}^{-1} \mathrm{~d} . \mathrm{m}$. (Anderson et al., 1999; Leblanc et al., 1999), how- ever, it exceeds the hyperaccumulation level indicated by van der Ent et al. (2013), i.e., $100 \mu \mathrm{g} \cdot \mathrm{g}^{-1}$ (100 mg. $\mathrm{kg}^{-1}$ ) d.m. This proves that B. laevigata is a thallium hyperaccumulator, especially since the study was conducted in laboratory conditions. The $\mathrm{Tl}$ amount in the B. laevigata plants much smaller than reported by Anderson et al. (1999) and Leblanc et al. (1999) may be an effect of too low Tl bioavailability in the calamine soil. After the extraction with EDTA, the estimated Tl bioavailability for plants was $3.1 \mathrm{mg} \cdot \mathrm{kg}^{-1} \mathrm{~d} . \mathrm{m}$., and after the extraction with $\mathrm{CaCl}_{2}, 1.1 \mathrm{mg} \cdot \mathrm{kg}^{-1} \mathrm{~d} . \mathrm{m}$. (Tab. 2). After water extraction, Kicińska (2009) estimated the Tl bioavailability as even lower: 0.1-0.8 $\mathrm{mg} \cdot \mathrm{kg}^{-1} \mathrm{~d} . \mathrm{m}$.

The $\mathrm{Tl}$ content in the B. laevigata plants evidences their ability to hyperaccumulate this element. Of the total thallium content $16 \%$ was accumulated in the roots and $84 \%$ was transported to the leaves. The $\mathrm{Tl}$ accumulation pattern was as follows: fresh leaves $>$ roots $>$ the oldest drying leaves. The translocation factor was high; it reached 6.1 on average. The bioconcentration factor relating the $\mathrm{Tl}$ amount in shoots to its content in the soil also turned out high (10.9). It should be pointed out that both high $(>1)$ root-to-shoot translocation and shoot-to-soil bioconcentration factors for metals are characteristic of hyperaccumulators (van der Ent et al., 2013 and references therein). The results of this study indicate that $B$. laevigata is a facultative thallium hyperaccumulator. In our opinion the ability to hyperaccumulate this element is a species-wide trait, common to plants of both subspecies, independent of their natural occurrence in Tl contaminated and uncontaminated habitats. Pošcić et al. (2013), who had studied in laboratory conditions B. laevigata plants from different populations - on zinc-lead waste heaps in southern France (Les Avinières), northeastern Italy (Cave del Predil) and southern Poland (Bolesław near Olkusz) as well as an area uncontaminated with metals (Polish Tatra Mts.), came to other conclusions. The authors indicated a notably varied tolerance of the plants to the high $\mathrm{Tl}$ content in the soil - from hyperaccumulation (translocation factor $>1$; population from Les Avinières), through enhanced tolerance (populations from Italy and Bolesław) to inability to survive (Tatra population). According to the authors, the ability to hyperaccumulate thallium is a trait typical of a given population, and it is not common to the whole species. Similarly, after analyzing only elementary composition of the soil and plant specimens collected from metalliferous and uncontaminated areas in northeastern Italy, Pošcić et al. (2015) found a high interpopulation variability in the Tl content in plants. From among 15 populations studied, one was distinguishable by the Tl hyperaccumulation in shoots (Cave del Predil population; translocation and bioconcentration factors $>1$ ), and two (copper mine area, Avanza and former zinc 
and lead mine, Salafossa) had a $\mathrm{Tl}$ amount that was increased but still smaller than the accepted boundary of $100 \mu \mathrm{g} \cdot \mathrm{g}^{-1}$ (100 $\mathrm{mg} \cdot \mathrm{kg}^{-1}$ ) d.m. (van der Ent et al., 2013). Only these three of all populations occurred in metalliferous areas. It should be emphasized that those results were obtained in natural, and not in laboratory conditions. The discrepancy between reports on whether metal hyperaccumulation is a species-wide or population-specific trait was pointed out by Pollard et al. (2014). The authors' conclusion was that this issue certainly needed further study and explanation. Our results strongly support the idea that hyperaccumulation of metals is common for plants at the species rather than population level.

The toxic activity of thallium is due to its similarity to potassium and therefore its competition ability (Scheckel et al., 2007). Our study showed that the $\mathrm{K}$ uptake by the B. laevigata plants was ca. 10 times lower when plants grew in the calamine soil containing $\mathrm{Tl}$ in comparison to the garden soil (Tab. 5). In both soil types the $\mathrm{K}$ content was sufficient (Tab. 2).

The fact that the $\mathrm{K}$ uptake was much lower in plants having an increased $\mathrm{Tl}$ amount indicates competition between the two elements. A similar relationship was discovered during the study on Sinapis alba, when thallium was added to the soil as thallium sulphate. There occurred competition between the K and Tl uptake (Vanĕk et al., 2010). According to Wenzel and Jockwer (1999), there is some evidence that potassium may play a role in heavy metal ion compartmentation in hyperaccumulating species; however, a precise mechanism has not been described yet.

\section{THALLIUM DISTRIBUTION IN LEAF LAMINAS AND TRICHOMES}

As thallium was located in the greatest amount in fully developed leaves of the B. laevigata plants, its distribution there was checked by LA-ICP-MS. It turned out that the smallest $\mathrm{Tl}$ amount was at the top of a leaf, whereas the largest one was at its base. In the leaves of another species, Iberis intermedia, a similar pattern of $\mathrm{Tl}$ distribution was detected using synchrotron X-ray differential absorption edge computed microtomography (CMT) (Scheckel et al., 2007).

In this study it was shown by means of the sensitive LA-ICP-MS method that a considerable $\mathrm{Tl}$ amount was accumulated in the leaf trichomes of $B$. laevigata. An important role of trichomes in hyperaccumulation of other metals has also been proved in other plant species, e.g., zinc and cadmium in Arabidopsis halleri (Küpper at al., 2000) or nickel in the Alyssum genus (Broadhurst et al., 2004a, 2004b).
Accumulation of metals in trichomes is a way to protect the metabolism of active cells against metal toxicity (Küpper et al., 2000). The specialized trichome cells trap and accumulate a very high content of metals (15-20\% of dry mass in Alyssum), which might be a general rule in hyperaccumulating plant species (Broadhurst et al., 2004b).

In this study it was shown for the first time that thallium is accumulated in leaf trichomes of plants from both B. laevigata populations. Therefore, the trichomes play an important role in the protection of other leaf cells against the toxicity of thallium, and an increased number of trichomes on leaves favors plant growth in the habitat enriched in this element.

In our previous study (Wierzbicka and Pielichowska, 2004) it was shown that the trichome number on leaves is one of the main traits distinguishing the calamine $B$. laevigata population from the montane one.

The leaves were $50-100 \%$ covered with trichomes in the calamine population and $5-50 \%$ in the montane one. Thus, the leaf trichomes were more numerous in the calamine than in the montane population. This trait is genetically preserved because it occurred in plants cultivated in the same laboratory conditions. To sum up, $\mathrm{Tl}$ accumulation is the most possible in leaf trichomes of B. laevigata plants growing on the zinc-lead waste heap.

\section{CONCLUSION}

It has been proved in controlled laboratory conditions that Polish B. laevigata plants, regardless of their origin (i.e., the Bolesław calamine waste heap vs West Tatra montane populations) are able to hyperaccumulate thallium: to take it up by the roots from the calamine soil and to transport it mainly to fresh leaves. Therefore, we conclude that the ability to hyperaccumulate $\mathrm{Tl}$ is a species-wide rather than population-specific trait. This ability turned out to be related to the age of plants and it was the highest in the young ones.

It has been shown for the first time by the LA-ICP-MS method that B. laevigata plants detoxify $\mathrm{Tl}$ by removing it into leaf trichomes. Though present in both populations, the trichomes were more numerous in the calamine than in the montane plants, which indicates stronger adaptation of the former to growing on the zinc-lead waste heap.

\section{AUTHORS' CONTRIBUTIONS}

MW conceptual work, study supervision, manuscript elaboration; MP conducting experiments and processing data; AA chemical analyses of thallium; 
BW collecting material and elaborating analytical results; IW chemical analyses by LA-ICP-MS; EB supervising study done by methods of analytical chemistry; DPM final manuscript preparation.

\section{ACKNOWLEDGEMENTS}

This research was financially supported by the Polish Ministry of Science and Higher Education as a promoter research project no. 2 PO4C 03528 and a grant BW no. 501/68/1561/02/50.

\section{REFERENCES}

Anderson CWN, Brooks RR, Chiarucci A, Lacoste CJ, LebLANC M, Robinson BH, SiMCOCK R, and STEWART RB. 1999. Phytominig for nickel, thallium and gold. Journal of Geochemical Exploration 67: 407-415.

Broadhurst CL, Chaney RL, Scott Angle J, Erbe EF, and MauGEL TK. 2004a. Nickel localization and response to increasing $\mathrm{Ni}$ soil levels in leaves of the Ni hyperaccumulator Alyssum murale. Plant and Soil 265: 225-242.

Broadhurst CL, Chaney RL, Scott Angle J, Maugel TK, ERBE EF, and MurPhy CA. 2004b. Simultaneous hyperaccumulation of nickel, manganese, and calcium in Alyssum leaf trichomes. Environmental Science and Technology 38: 5797-5802.

CRÖßMANN G. 1984. Thallium - a new environmental problem? Angewdte Botanik 58(1): 3-10.

DMowski K. 2000. Chapter 17 Environmental monitoring of heavy metals with magpie (Pica pica) feathers - an example of Polish polluted and control areas. In: Markert B, Friese K. [eds], Trace Elements: Their Distribution and Effects in the Environment, Trace Metals and the Environment 4, 455-477. Elsevier BV, Amsterdam.

DMowsKi K, and BADUREK M. 2001. Thallium contamination of selected biotic elements of ecosystems neighboring the zinc smelter in Bukowno. In: Gworek B, Mocek A. [eds], Obieg pierwiastków $w$ przyrodzie, Monografia. Vol. I. 19-23. Instytut Ochrony Środowiska, Warszawa.

DMowsKi K, and BADUREK M. 2002. Thallium contamination of selected plants and fungi in the vicinity of the Bolesław zinc smelter in Bukowno (S. Poland). Preliminary study. Acta Biologica Cracoviensia Series Botanica 44: 57-61.

DMowski K, KozaKiewicz A, and KozaKiewicz M. 1998. Small mammal population and community under conditions of extremely high thallium contamination in the environment. Ecotoxicology and Environmental Safety 41: 2-7.

DoBRZAŃSKA J. 1955. Badania florystyczno-ekologiczne nad roślinnością galmanową okolic Bolesławia i Olkusza [Flora and ecological studies on calamine flora in the district of Bolesław and Olkusz]. Acta Societatis Botanicorum Poloniae 24: 357-408.

Epstein AL, Gussman CD, Blaylock MJ, Yermiyahu U, Huang JW, KAPULNIK Y, and ORSER CS. 1999. EDTA and Pb-EDTA accumulation in Brassica juncea grown in $\mathrm{Pb}$-amended soil. Plant and Soil 208: 87-94.
Escarré J, Lefèbvre C, Raboyeau S, Dossantos A, Gruber W, Cleyet Marel JC, Frérot H, Noret N, Mahieu S, ColLIN C, and VAN OORT F. 2011. Heavy metal concentration survey in soils and plants of the Les Malines Mining District (Southern France): implications for soil restoration. Water Air and Soil Pollution 216: 485-504.

FRATTINI P. 2005. Thallium properties and behaviour - a literature study. Geological Survey of Finland. http://arkisto. gtk.fi/s41/S41_0000_2005_2.pdf.

GoDzIK B. 1984. Tolerancja wybranych gatunków roślin na metale ciężkie [Tolerance of selected plant species to heavy metals]. PhD dissertation, W. Szafer Institute of Botany, Polish Academy of Sciences, Kraków.

GoDzIK B. 1991. Accumulation of heavy metals in Biscutella laevigata (Cruciferae) as a function of their concentration in the substrate. Polish Botanical Studies 2: 241-246.

GoDZIK B. 2015. Natural and historical values of the Olkusz Ore-bearing Region. W. Szafer Institute of Botany, Polish Academy of Sciences, Kraków.

GrodzińsKa K, KORZENIAK U, SZAREK-ŁUKASZEWSKA G, and GoDziK B. 2000. Colonization of zinc mine spoils in southern Poland - preliminary studies on vegetation, seed rain and seed bank. Fragmenta Floristica and Geobotanica 45: 123-145.

GrodzińsKa K, and SzareK-ŁuKaszewsKa G. 2002. Hałdy cynkowo-ołowiowe w okolicach Olkusza - przeszłość, teraźniejszość i przyszłość [Zinc-lead waste heaps in the environs of Olkusz - the past, the present and the future]. Kosmos - Problemy Nauk Biologicznych 51: 127-138.

Hanć A, Baratkiewicz D, Piechalak A, Tomaszewska B, WaGNER B, and Bulska E. 2009. An analysis of long-distance root to leaf transport of lead in Pisum sativum plants by laser ablation-ICP-MS. International Journal of Environmental Analytical Chemistry 89(8-12): 651-659.

Heil DM, Samani Z, Hanson AT, and Rudd B. 1999. Remediation of lead contaminated soil by EDTA. I. Batch and column studies. Water Air and Soil Pollution 113: 77-95.

Kabata-Pendias A. 2011. Trace elements in soils and plants. CRC Press, Boca Raton, US.

KICIŃSKA A. 2009. Arsen i tal w glebach i roślinach rejonu Bukowna [Arsenic and thallium in the soil and plants in the area of Bukowno]. Ochrona Środowiska i Zasobów Naturalnych 40: 199-208.

Küpper H, Lombi E, Zhao FJ, and McGrath SP. 2000. Cellular compartmentation of cadmium and zinc in relation to other metals in the hyperaccumulator Arabidopsis halleri. Planta 212: 75-84.

Lacoste C, Robinson B, and Brooks R. 2001. Uptake of thallium by vegetables: its significance for human health, phytoremediation, and phytomining. Journal of Plant Nutrition 24(8): 1205-1215.

Lacoste C, Robinson B, Brooks R, Anderson C, Chiarucci A, and LEBLANC M. 1999. The phytoremediation potential of thallium-contaminated soils using Iberis and Biscutella species. International Journal of Phytoremediation 1(4): 327-338.

Leblanc M, Petit D, Deram A, Robinson BH, and Brooks R. 1999. The phytomining and environmental significance of hyperaccumulation of thallium by Iberis intermedia from Southern France. Economic Geology 94: 109-114. 
LiPHADZI MS, KiRKham MB, MANKIn KR, and PAULSEn GM. 2003. EDTA-assisted heavy-metal uptake by poplar and sunflower grown at a long-term sewage-sludge farm. Plant and Soil 257: 171-182.

Lis J, Pasieczna A, Karbowska B, ZembrZuski W, and ŁUKASZEWSKI Z. 2003. Thallium in soils and stream sediments of a $\mathrm{Zn}-\mathrm{Pb}$ mining and smelting area. Environmental Science and Technology 37: 4569-4572.

Minczewski, J, Marczenko Z. 2004. Chemia analityczna. Chemiczne metody analizy ilościowej [Analytical chemistry. Chemical methods of quantitative analysis]. Vol. II, PWN, Warszawa.

NRIAGU J.O. 1998. Thallium in the environment. Advances in Environmental Science and Technology 29, Wiley and Sons, New York.

Olko A, Abratowska A, ŻyŁkowska J, Wierzbicka M, and TukienDORF A. 2008. Armeria maritima from a calamine heap - Initial studies on physiologic-metabolic adaptations to metal-enriched soil. Ecotoxicology and Environmental Safety 69: 209-218.

Pollard AJ, Reeves RD, and Baker AJM. 2014. Facultative hyperaccumulation of heavy metals and metalloids. Plant Science 217-218: 8-17.

Pošćić F, Marchiol L, and Schat H. 2013. Hyperaccumulation of thallium is population-specific and uncorrelated with caesium accumulation in the thallium hyperaccumulator, Biscutella laevigata. Plant and Soil 365: 81-91.

Pošćć F, Fellet G, Vischi M, Casolo V, Schat H, and MarCHIOL L. 2015. Variation in heavy metal accumulation and genetic diversity at a regional scale among metallicolous and non-metallicolous populations of the facultative metallophyte Biscutella laevigata subsp. laevigata. International Journal of Phytoremediation 17(5): 464-475.

SAGER M. 1994. Thallium. Toxicological and Environmental Chemistry 45(1-2): 11-32.

Scheckel KG, Lombi E, Rock SA, and Mclaughlin MJ. 2004. In vivo synchrotron study of thallium speciation and compartmentation in Iberis intermedia. Environmental Science and Technology 38: 5095-5100.

Scheckel KG, Hamon R, Jassogne L, Rivers M, and Lombi E. 2007. Synchroton X-ray absorption-edge computed microtomography imaging of thallium compartmentalization in Iberis intermedia. Plant and Soil 290: 51-60.

SEREGIN IV, and IvANov VB. 1997. Histochemical investigation of cadmium and lead distribution in plants. Russian Journal of Plant Physiology 44: 791-796.

Sheoran V, Sheoran AS, and Poonia P. 2009. Phytomining: A review. Minerals Engineering 22: 1007-019.

SzAFER W. 1927. Flora Polska: Rośliny naczyniowe Polski $i$ ziem ościennych [The Polish flora: Vascular plants of Poland and neighbouring areas]. Vol. III, Polska Akademia Umiejętności (PAU), Kraków.

SZAREK- ŁUKASZEWSKA G, and NiKLIŃSKA M. 2002. Concentration of alkaline and heavy metals in Biscutella laevigata L. and Plantago lanceolata L. growing on calamine spoils (S. Poland). Acta Biologica Cracoviensia Series Botanica 44: 29-38.
SzMAL ZS, and LIPIEC T. 1996. Chemia analityczna $z$ elementami analizy instrumentalnej [Analytical chemistry with the elements of instrumental analysis]. Wydawnictwo Lekarskie PZWL, Warszawa.

Turgut C, Pepe MK, and Cutright TJ. 2004. The effect of EDTA and citric acid on phytoremediation of $\mathrm{Cd}, \mathrm{Cr}$ and $\mathrm{Ni}$ from soil using Helianthus annuus. Environmental Pollution 131: 147-154.

Xiao T, Guha J, Boyle D, Liu C-Q, and Chen J. 2004. Environmental concerns related to high thallium levels in soils and thallium uptake by plants in southwest Guizhou, China. Science of the Total Environment 318: 223-244.

WÁCHALEWSKI T. 1999. Kwasowość czynna i potencjalna gleby [Active and potential acidity of soil]. In: SzczepaniecCięciak E, Kościelniak P. [eds], Chemia środowiska: ćwiczenia $i$ seminaria, Vol. II. 21-24. Uniwersytet Jagielloński, Kraków.

WenZel WW, and JockWER F. 1999. Accumulation of heavy metals in plants grown on mineralized soils of the Austrian Alps. Environmental Pollution 104: 145-155.

WierzBicka M, and PielichowsKa M. 2004. Adaptation of Biscutella laevigata L., a metal hyperaccumulator, to growth on a zinc-lead waste heap in southern Poland. I: Differences between waste-heap and mountain populations. Chemosphere 54: 1663-1674.

WiERzBicka M, SZAREK-ŁUKASZEWSKA G, and GRODZińSKA K. 2004. Highly toxic thallium in plants from the vicinity of Olkusz (Poland). Ecotoxicology and Environmental Safety 59(1): 84-88.

Wierzbicka M, Dutkiewicz J, Wysocka I, Bulska E, and JansSENS K. 2007. Biotransformacja selenu w roślinach [Biotransformation of selenium in plants]. In: Wierzbicka M, Bulska E, Pyrzyńska K, Wysocka I, Zachara BA [eds], Selen pierwiastek ważny dla zdrowia, fascynujacy dla badacza, 88-102. Wyd. Malamut. Warszawa.

WóYcicki Z. 1913. Obrazy roślinności Królestwa Polskiego [Vegetation in the Kingdom of Poland]. IV Roślinność terenów galmanowych Bolesławia $i$ Olkusza [The calamine flora of Boleslaw and Olkusz], Kasa Mianowskiego, Warszawa.

WysockA I. 2004. Badanie specjacji i metabolizmu selenu w roślinach metoda chromatografii cieczowej połączonej ze spektrometria mas ze wzbudzeniem w plazmie indukcyjnie sprzężonej [The study on speciation and metabolism of selenium in plants with use of the liquid chromatography method coupled with ICP-MS]. PhD dissertation, Wydział Chemii, Uniwersytet Warszawski.

VAn Der Ent A, BaKer AJM, Reeves RD, Pollard AJ, and Schat H. 2013. Hyperaccumulators of metal and metalloid trace elements: Facts and fiction. Plant and Soil 362: 319-334.

VAnĚK A, Komárek M, Chrastnỳ V, BečKa D, Mihaluevič M, ŠEBeK O, PANǔsková G, and Schusterová Z. 2010. Thallium uptake by white mustard (Sinapis alba L.) grown on moderately contaminated soils-Agro-environmental implications. Journal of Hazardous Materials 182: 303-308. 